\title{
PERFORMANCE EVALUATION OF SUGAR BEET TWO SPLIT HARVESTERS UNDER EGYPTIAN CONDITIONS
}

\author{
ELSHABRAWY, H $^{1} \quad$ R. M. SALIM ${ }^{2} \quad$ Barakat, R. R. $^{3}$
}

\begin{abstract}
The main objectives of this study were to evaluate the performance of using two split of harvester for topping and lifting the sugar beet crop at the same time that means a complete harvesting process for sugar beet crop. Measuring indicators were tested for the two split harvester (Grimme BM300 and Rootster 604) at the tested forward speed $(\mathrm{m} / \mathrm{s})$, type of cleaning system (axial or turbine) and type of opal wheel driven (ground and hydraulically). It was found that using the tested harvester with turbine cleaning system and with hydraulically driven under forward speed of $5.8 \mathrm{~km} / \mathrm{h}$ gave the best results in all treatments. Forward speed of $3.5 \mathrm{~km} / \mathrm{h}$ gave desirable results with some measurements. Therefore it is advisable to use the harvester with hydraulically driven and turbine cleaning system with forward speed of $5.8 \mathrm{~km} / \mathrm{h}$ that showed the best results while harvesting the sugar beet crop.
\end{abstract}

\section{INTRODUCTION}

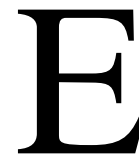

fforts have been exerted for increasing sugar production to overcome the gap between the people consumption and production. It has been recommended to increase beet production area because of the limitation of water sources required for increasing sugar cane production area. Although, sugar beet harvesting is one of the most labor consuming operations; yet harvesting machines are still not widely used in developing countries including Egypt. Mechanical sugar beet harvesters are not common in Egypt, and manual methods are exhaustive, and impractical. Sugar beet harvesting is carried out in Egypt manually by hand digging, pulling the roots out by shovel and hoe or by

1 - Professor. of Agricultural Engineering, Faculty of Agriculture, Mansoura University

2 - Senior Researcher of Agricultural Engineering, Agric. Eng. Res. Institute

3 - Agricultural expert associate at the ministry of justice 
using a chisel plow and collecting the roots manually. In the recent time various types of machines are available for harvesting sugar beet crop. They are operated on entirely different principles to each other's. Whatever the harvester classification, it has to lift the sugar beet crop, out of the ridge and by passing them through different sections of the implement to separate them from loose soil, soil clods, tops and any other rubbish. This will normally be when the center point of any lifting unit is positioned in the ridge center. Aly (1998) explained that the maximum force needed to cut the beet in the upper part was $540 \mathrm{~N}$, in the middle part of $430 \mathrm{~N}$ and the root part was $188 \mathrm{~N}$ and the cutting resistance was an inversely proportional of cutting velocity. Kromer et, al. (1998) found that the harvesters today have field capacities from 40 to $130 \mathrm{t} / \mathrm{h}$, tank capacities from 5.5 (2-row) to $26 \mathrm{t}$ (6-row) and average harvesting qualities of $5.8 \%$ dirt tare, $1.9 \%$ total mass loss and $75.1 \%$ acceptable topping. Ivancan et, al. (2002) reported that losses due to the top root breakage amounted to $8.4 \%$ of yield at a speed of $1.2 \mathrm{~km} / \mathrm{h}$, and to $18.3 \%$ at a speed of $6.5 \% \mathrm{~km} / \mathrm{h}$. Surface and underground losses ranged from 2.3 to $4.1 \%$ of yield. Underground losses were a consequence of the performance of the lifting mechanisms and, depending on the working speed, ranged from 1.4 to $2.6 \%$ of yield. The lowest underground losses were recorded at speed of $1.2 \mathrm{~km} / \mathrm{h}$, and the highest at the speed of 6.5 $\mathrm{km} / \mathrm{h}$.

Sharobeem et, al. (2003) developed and manufactured suitable equipment for lifting sugar beet roots. The results showed that, for the developed lifter, the maximum a lifting efficiency was about $84 \%$ at 2 $\mathrm{km} / \mathrm{h}$ forward speed and the minimum damage roots was about $4.5 \%$ at the same speed. The maximum percentage of lifted roots was about 88.5 $\%$ with the developed lifter, while that obtained with chiseling was 76.4 $\%$. The actual field capacities were $0.6,0.9$ and $1.14 \mathrm{fed} / \mathrm{h}$ at forward speeds of 2, 3 and $3.8 \mathrm{~km} / \mathrm{h}$ respectively, for the developed lifter.Also, they added that in case of using the developed lifter, the minimum power required was $13.16 \mathrm{~kW}$ at forward speed of $2 \mathrm{~km} / \mathrm{h}$. while the maximum power required was about $25.96 \mathrm{~kW}$ at $3.8 \mathrm{~km} / \mathrm{h}$ forward speed. The energy requirement for the developed lifter was about $22.77 \mathrm{~kW} . \mathrm{h} / \mathrm{fed}$. Abd- Rabou (2004) concluded that decreasing forward speed tended to 
decrease total damaged roots. It is clear that, increasing forward speed from 0.55 to $1.06 \mathrm{~m} / \mathrm{s}$ tends to increase the total damaged root from 4.51 to $5.4 \%$. The highest value of the total damaged roots of $6.2 \%$ was obtained at forward speed of $1.6 \mathrm{~m} / \mathrm{s}$, the lowest value of the total damaged 3.4\% was obtained at forward speed of $0.55 \mathrm{~m} / \mathrm{s}$. Awad (2006) mentioned that using developed harvester decreased unit cost by decrement from 66.15 to $68.66 \%$ comparing by the digger techniques. Khallil (2007) mentioned that decreasing forward speed and increasing share depth tends to decrease total damage root at all types of lifting blades for mechanical and traditional planting methods. The minimum value of harvesting losses reach to $2 \%$ at lifting depth of $25 \mathrm{~cm}$, forward speed of $1.2 \mathrm{~km} / \mathrm{h}$ for mechanical planting by using fork lifter. He mentioned that the maximum harvesting eff. was reached to $95.1 \%$ at 1.2 $\mathrm{km} / \mathrm{h}$ by using the fabricated machine with fork lifter at mechanical planting methods.

Therefore, the main objective of the present investigation is to choose a suitable mechanism for topping and lifting sugar beet roots. To study the possibility of utilizing it under the Egyptian new reclaimed land and to suit large holding farms of investment companies using available power tiller on farms. Field experiments were carried out to evaluate the performance of two split harvesters at different forward speeds, two type of cleaning system and two type of opal wheel driver. Topping efficiency, the tare ratio, cleaning ratio, fuel consumption and the cost of harvesting operation were therefore studied.

\section{MATERIALS AND METHODS}

Al-Nouran advanced company decided planting of 6000 feddan sugar beet in land new reclaimed under pivot irrigation system to choose the suitable harvesting method from the harvesting system in the world. The main objective of this study is to evaluate the performance of using two split the first one defoliator (BM300) and the second one harvester (Rootster 604) for topping and lifting the sugar beet crop and to choose the suitable options for Egyptian sugar beet harvesting conditions. A field experiments were carried out in new reclaimed land under pivot 
irrigation system in Al- Nouran advanced company in Salihia Sector, AlSharkia Governorate to harvest sugar beet in a large holding area (pivots) and evaluate machine performance during the harvesting operation for the first time in Egypt. The experimental crop of the present study was sugar beet monogermel (cesira). The chosen variety was planted in an area of about 600 feddans. Measuring indicators were tested for the two split harvester (BM 300 and Rootster 604) at the tested forward speed $(\mathrm{m} / \mathrm{s})$, type of cleaning system (axial or turbine) and type of opal wheel (ground driven and hydraulically driven) for sugar beet.

Machine used:

Technical data of the used defoliators (BM300) (first split)

\begin{tabular}{|c|c|}
\hline & BM300 \\
\hline Length & $5,600 \mathrm{~mm}\left(6,700 \mathrm{~mm}^{*}\right)$ \\
\hline Width & $3,600 \mathrm{~mm}$ \\
\hline Height & $1,300 \mathrm{~mm}$ \\
\hline Weight & $2,300 \mathrm{~kg}(2,700 \mathrm{~kg} *)$ \\
\hline Row width & Adjustable between 45 and $56 \mathrm{~cm}$ \\
\hline Flail shaft & Continuous flail shaft with spirally arranged steel flails \\
\hline 1st cleaning shaft & $\begin{array}{l}\text { Rubber flails above beet row, row width mechanically } \\
\text { and steplessly adjustable; }\end{array}$ \\
\hline 2nd cleaning shaft & $\begin{array}{l}\text { Rubber flails above beet row, row width mechanically } \\
\text { and steplessly adjustable, }\end{array}$ \\
\hline Depth setting & $\begin{array}{l}\text { Lifting cylinder with spindle adjustable end stop in } \\
\text { front, tool-free adjustment of rear control wheels }\end{array}$ \\
\hline Tires & 4 x 7.5-20 TR 15 AS \\
\hline Operating/Setting & $\begin{array}{l}1 \text { double acting independent controller ( }+1 \text { single acting } \\
\text { controller with pressure-free return*) }\end{array}$ \\
\hline Drive & Mechanically: PTO-shaft 1,000 rpm with freewheeling \\
\hline Required power & At least: $60 \mathrm{~kW} / 82 \mathrm{HP}$, Recommended: $90 \mathrm{KW} / 120 \mathrm{HP}$ \\
\hline
\end{tabular}


Technical data of the used Grimme rootster 604) (second split)

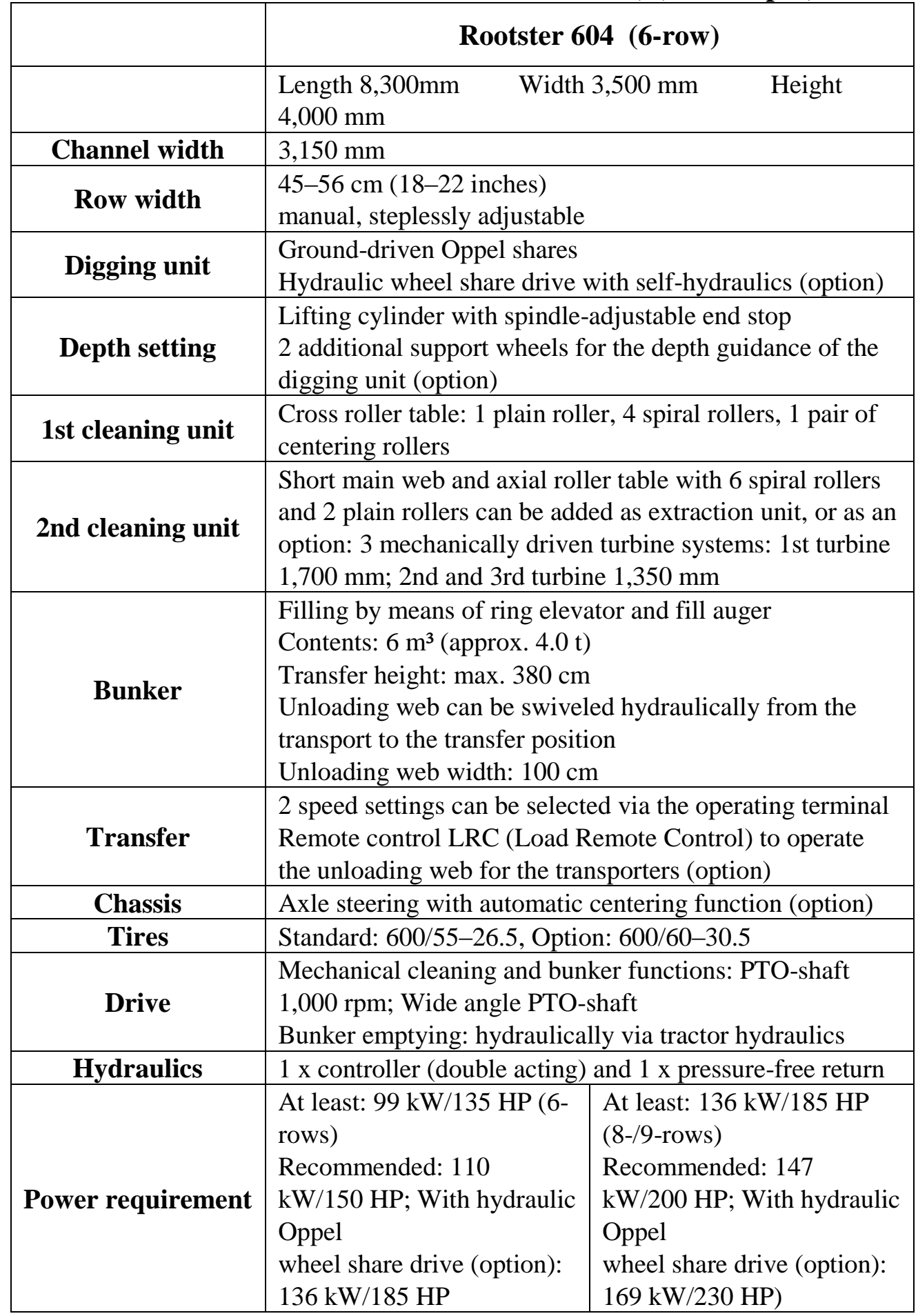




\section{Measuring instruments:}

1- Hand peeler: to remove a slice approximately $1.0 \mathrm{~mm}$ thick for damage classification.

2- Balance: to measure the mass of roots obtained from the plots of replicates an ordinary balance (accuracy of $1.0 \mathrm{~g}$ ).

3- Vernier caliper: to measure the dimension of roots size with accuracy $1 / 20 \mathrm{~mm}$.

4- Stopwatch to record the time consumed through a travel of 10 meters length for different units during execution the different experiments. Range, min: 30, Sensitivity: 1

5- Steel tape: to measure the length of the replicate tracks and both length and width of plots.

7- Fuel consumption apparatus: the fuel consumed during the harvesting operation was measured by using a fuel consumption apparatus. Its capacity is of about $750 \mathrm{ml}$. It has a reading ruler divided into 15 divisions. Each of the division is reading $50 \mathrm{ml}$.

8- Tachometer: to measure the rotation speed of shafts.

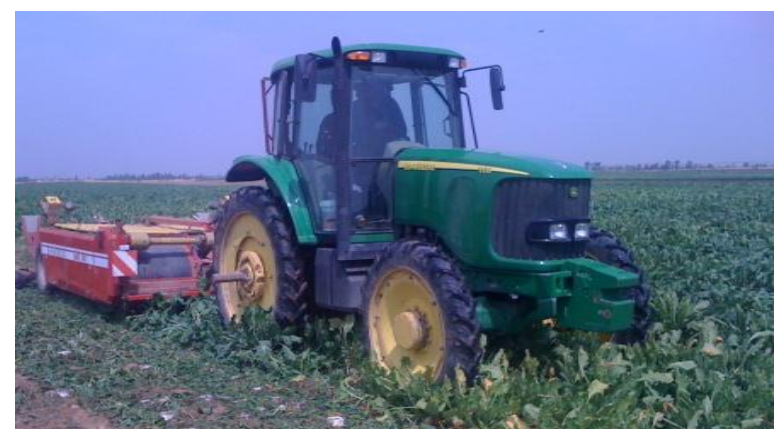

Figure (1) :The BM 300 grimme defoliator machine while working .

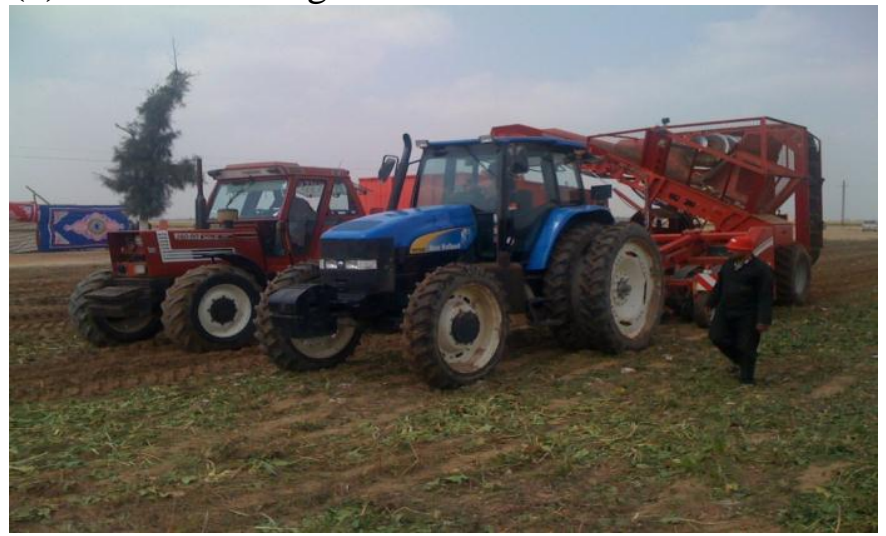

Figure (2) : The Rootster 604 Grimme harvester while working 


\section{Design of the experiment:}

In this research the experiments were carried out in an area pivot (each one pivot area 150 feddans). The dimension of every one pivot of about one $\mathrm{km}$ diameter and $3 \mathrm{~km}$ circumstance. Sugar beet seeds (cisera monogerme) variety was mechanically planted.

\section{Test factors}

The following parameters were studied to evaluate the performance of the harvester with four replicates for each parameter.

- Four forward speeds (3.5, 4.3, 5 and $5.8 \mathrm{~km} / \mathrm{h}$ ): Forward speed is calculated by measuring the necessary time to cover specified experiment and the travel distance

$$
V=\frac{S}{T \times 3.6} \mathrm{~km} / \mathrm{h}
$$

Where:

$\mathrm{V}=$ forward speed, $\mathrm{km} / \mathrm{h} ; \mathrm{S}=$ travel distance, $\mathrm{m}$ and $\mathrm{T}=$ time of experiment, $\mathrm{s}$.

- First split:

-Two types of rubber shaft (one rubber shaft $1 \mathrm{~S}$ and two rubber shafts $2 \mathrm{~S})$.

-Two types of rear cleaning (without scraper Ds1 and with scraper Ds2)

- Second split:

- Two types of opal wheel driver (ground driver $\mathrm{TW}_{1}$ and hydraulically driver TW2).

- Two types of cleaning system (axial system, $\mathrm{CS}_{1}$ and turbine system, $\mathrm{CS}_{2}$ ).

These measuring indicators were tested for the two split harvester (Grimme BM 300 and Rootster 604) at the tested forward speed $(\mathrm{m} / \mathrm{s})$, type of driven of opal wheel (ground and hydraulically) and type of cleaning system (axial or turbine) for sugar beet. The row width was adjusted at $45 \mathrm{~cm}$, the spaces between seeds were adjusted at $20 \mathrm{~cm}$ and the depth at $3 \mathrm{~cm}$ for sugar beet planting.

\section{Measurements:}

\section{1- Un topping beet (\%)}

The topping performance was evaluated by observing the sugar beet toper through, correct topped beet, un-topped beet, and topping 
efficiency. During the experimental work, the performance of topper assessed by taking randomly selected $30 \mathrm{~m}$ of work length, lifting the beet and collecting the tops. So untopped can be estimated easily. The percentage of the items, which are used to control topper performance, can be calculated as the following (Richey et al., 1961).

$$
\text { Untopped beet }=\frac{\text { No. of untopped beet }}{\text { Total No. of topped beet }+ \text { No of untopped beet }} \times 100
$$

Topping efficiency $=100-($ untopped beet,$\%+$ broken beet,$\%)$

\section{2- Tare ratio $(\%)$}

The tare ratio (Tr.) was calculated by the following equation:

$$
T_{r}=\frac{M_{\text {tare }}}{M_{\text {total }}} x 100
$$

Where:

Tr: tare ratio (\%), $\mathrm{M}_{\text {tare }}$ : mass of tare in simple $\mathrm{M}_{\text {total }}$ : total weight of sample

\section{3- Cleaning ratio $(\%)$}

The cleaning ratio calculated by the following equation:

$$
C_{1}=\frac{M_{c}}{M_{t}} x 100
$$

\section{Where:}

$\mathrm{C}_{1}$ : cleaning ratio $(\%), \quad \mathrm{M}_{\mathrm{c}}$ : mass of the sample after cleaning. $\mathrm{M}_{\mathrm{t}}$ : total mass of sample.

\section{4- Fuel consumption (1/h)}

Fuel consumption was experimental determined by using a fuel consumption apparatus its capacity of about $750 \mathrm{ml}$. It has a reading scale divided into 15 sections with accuracy of $50 \mathrm{ml}$. The rate of fuel consumption was calculated as quantity per unit time, as show in the following formula (Suliman et al., 1993).

$$
C . F .=\frac{f}{t} \times 3.6(l / h)
$$


Where:

C.F. $=$ Fuel consumption, $1 / \mathrm{h} ; \mathrm{f}=$ volume of fuel consumption, $\mathrm{cm}^{3}$ and, $\quad \mathrm{t}=$ time, $\mathrm{s}$.

The specific fuel consumption (S.F.C.) calculated by using the following formula (Suliman et al., 1993).

$$
\text { S.F.C }=\frac{\text { Fuel consumption }}{\text { Power consumed }}(l / k W . h)
$$

\section{The statistical analysis:}

The experiments were arranged in split plot design with three replicates by using Minitab software (Regression analysis and ANOVA). The analysis of variance was done to investigate the significance of the studied variables. Also, the best fit multiple linear regression equations and Regression Coefficient, $\mathrm{R}^{2}$ were developed for each variable.

\section{RESULTS AND DISCUSSION}

Untopped beets for two split harvester at the tested forward speed $\underline{(\mathrm{km} / \mathrm{h}) \text {, number of rubber flails shaft }(1 \mathrm{~S} \text { and } 2 \mathrm{~S}) \text { and attached rear }}$ $\underline{\text { scraper }} \mathrm{DS}_{1}$ and $\mathrm{DS}_{2}$ ) for sugar beet (Cesira).

The untopped beets percentage for the two split harvester at the tested forward speed $(\mathrm{km} / \mathrm{h})$, type of rubber flails shaft and attached disk scraper for sugar beet (Cesira) is presented on Figure (3). The achieved results revealed that both type of rubber flails and type of attached disk scalper for sugar beet harvester affected deeply the topped beets percentage at constant forward speed. The results showed that increasing forward speed resulted in decreasing topped beets percentage. The overall data showed that, with the two rubber flails shaft and attached disk scraper (with and without) under forward speed of 3.5, 4.3, 5 and $5.8 \mathrm{~km} / \mathrm{h}$, average of untopped beets percentage was $2.85,3.28,3.68$ and 4.0, respectively. From the figures, it was clear that the untopped beets percentage was higher at $\mathrm{ds}_{2}$ than $\mathrm{ds} 1$ attached disk scraper. The highest value of untopped beets percentage 4.27 with $\mathrm{ds}_{1}$ was obtained under forward speed of $5.8 \mathrm{~km} / \mathrm{h}$ while the lowest value of untopped beets percentage under the same conditions was 3.17 under forward speed of 
$3.5 \mathrm{~km} / \mathrm{h}$. Under $\mathrm{DS}_{1}$, the highest value of untopped beets percentage 3.73 and the lowest value of topped beets percentage 2.53 was achieved under the same conditions of $\mathrm{ds}_{2}$. Similar results and trends were observed under $2 \mathrm{~S}$ system. With $\mathrm{DS}_{2}$ system, the untopped beets percentage was less than using TW1 system. Also from the figure, untopped beets percentage was higher in $\mathrm{DS}_{1}$ than $\mathrm{DS}_{2}$ system. Data analyzed showed that there was a significant effect for using one shaft rubber flails and with using two shaft rubber flails $(p<0.01)$ under the same conditions of forward speed, number of rubber flail shaft and rear attached scraper systems.

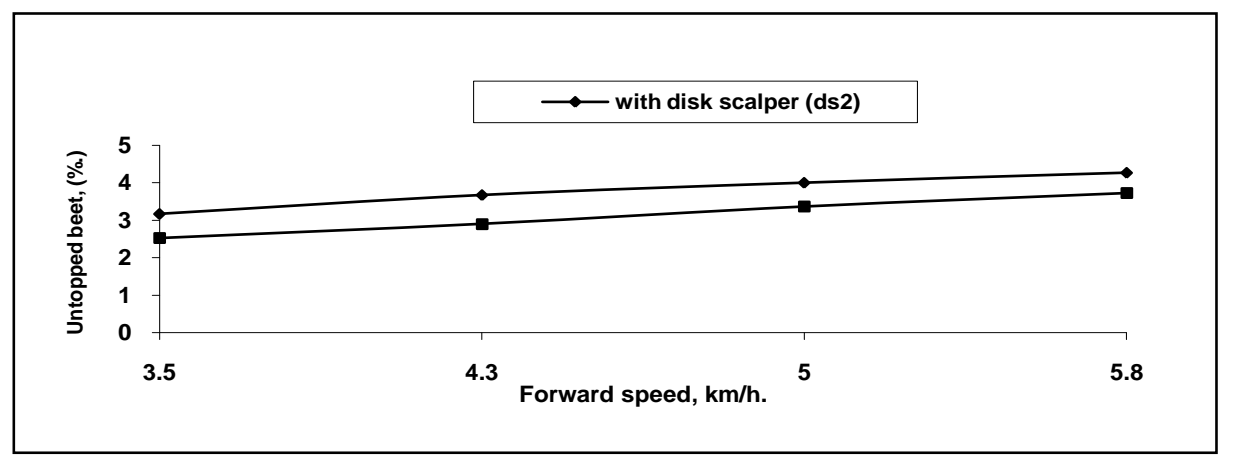

Figure. $3_{\mathrm{a}}$ : The untopped beet $(\%)$ for the two split harvester at the tested forward speed $(\mathrm{km} / \mathrm{h})$, number of rubber flail shaft and rear attached scraper for sugar beet (Cesira).

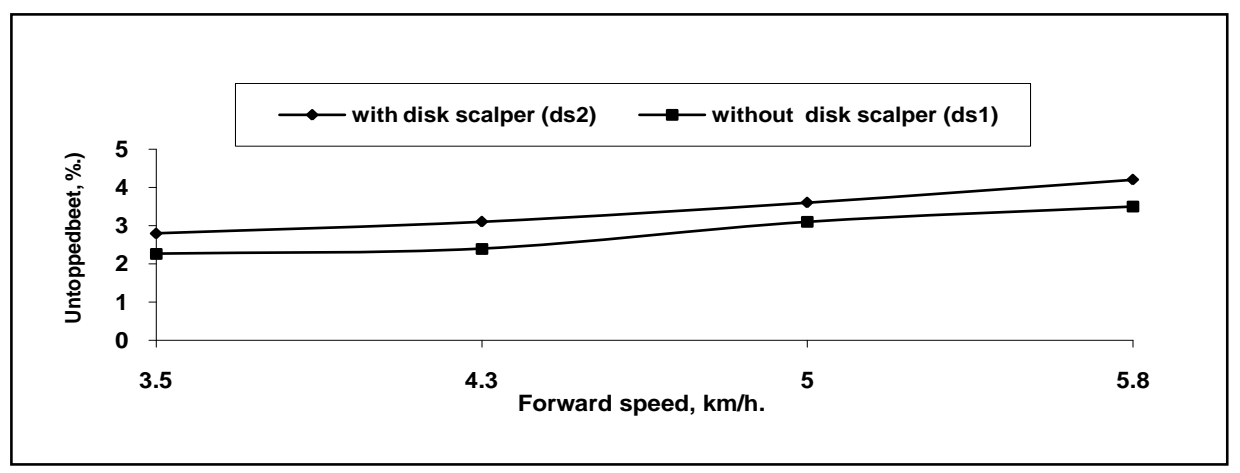

Figure. $3_{\mathrm{b}}$ : The topped beet $\%$ ) for the two split harvester at the tested forward speed $(\mathrm{km} / \mathrm{h})$, type number of rubber flail shaft and rear attached scraper for sugar beet (Cesira). 


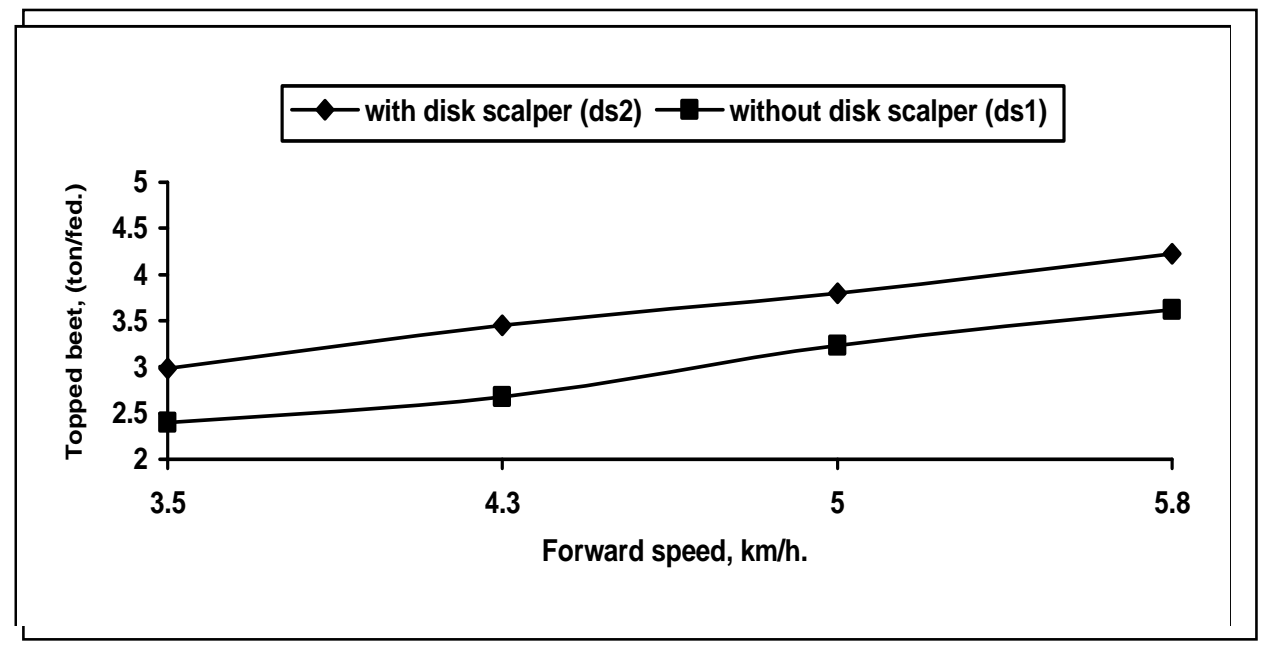

Figure. $3_{\mathrm{c}}$ : Average of the untopped beet $(\%)$ for the two split harvester at the tested forward speed $(\mathrm{km} / \mathrm{h})$, number of rubber flail shaft and rear attached scraper for sugar beet (Cesira).

The tare ratio (\%) for the two split harvester at the tested forward speed $(\mathrm{km} / \mathrm{h})$, type of cleaning system and type of opal wheel driver for sugar beet (Cesira).

Tare ratio (\%) for the two split harvester at the tested forward speed $(\mathrm{km} / \mathrm{h})$, type of cleaning system and type of opal wheel driver for sugar beet (Cesira) is presented on Figures. 4. The results showed that increasing forward speed resulted in increasing tare ratio, \% under different cleaning system and different opal wheel driver. It was found that increasing forward speed from 3.5 to $4.3 \mathrm{~km} / \mathrm{h}$ resulted in increasing tare ratio from 4.37 to $4.95 \%$ with TW1 system under axial. Similar trend was shown with forward speed of 5 and $5.8 \mathrm{~km} / \mathrm{h}$. Tare ratio was 5.34 and $6.31 \%$ with TW1 system and axial cleaning. On the other hand with turbine cleaning and TW1 system, the tare ratio was 4.18, 4.47, 4.96 and $5.71 \%$ under forward speed of $3.5,4.3,5$ and $5.8 \mathrm{~km} / \mathrm{h}$, respectively. It was clear that the tare ratio was higher with axial than turbine. These results may be due to the excessive amount of yield on the belt. 


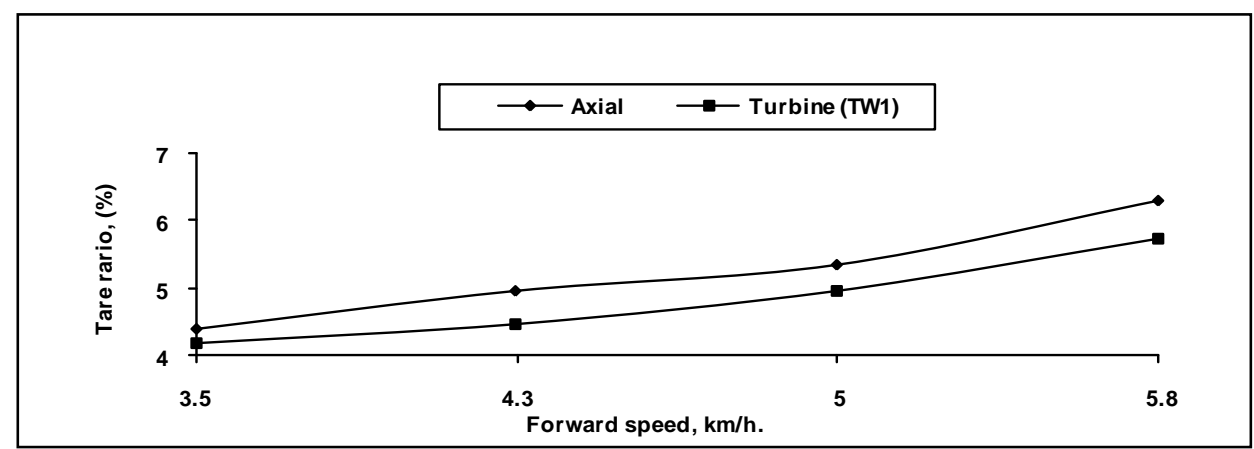

Figure. $4_{\mathrm{a}}$ : The tare ratio (\%) for the two split harvester at the tested forward speed $(\mathrm{m} / \mathrm{s})$, type of cleaning system and type ground driven opal wheel driver for sugar beet

(Cesira monogerme seeds).

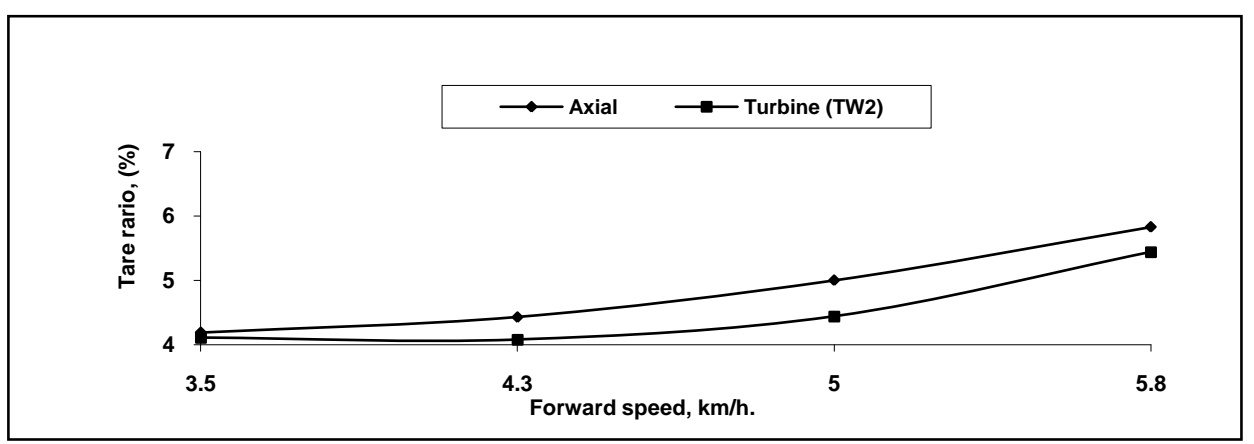

Figure. $4_{\mathrm{b}}$ : The tare ratio $(\%)$ for the two split harvester at the tested forward speed $(\mathrm{m} / \mathrm{s})$, type of cleaning system and type with hydraulically driven opal wheel driver for sugar beet (Cesira monogerme seeds).

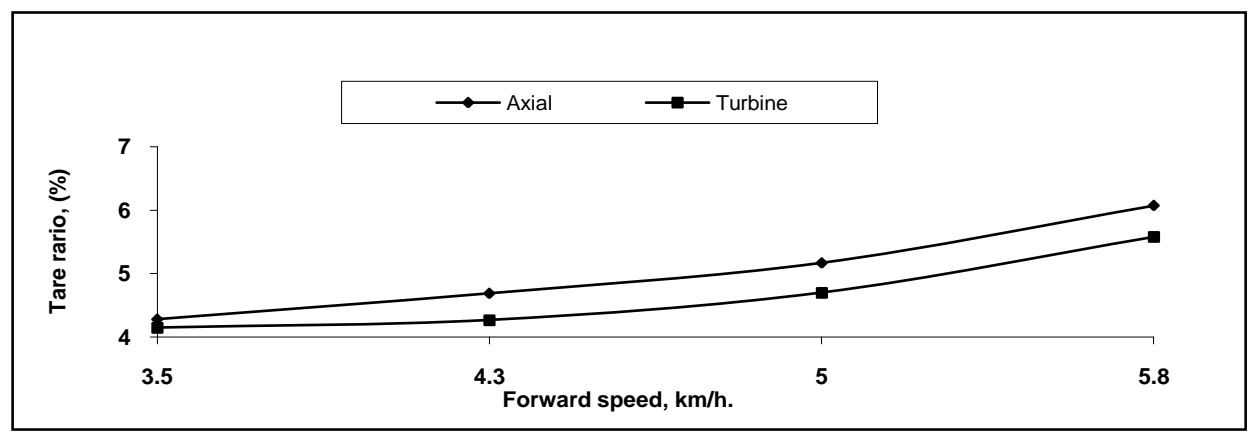

Figure. $4_{\mathrm{c}}$ : Average of tare ratio (\%) for the two split harvester at the tested forward speed $(\mathrm{m} / \mathrm{s})$, type of cleaning system and two types of opal wheel driver for sugar beet (Cesira monogerme seeds).

The highest value of tare ratio $6.31 \%$ with axial cleaning was obtained under forward speed of $5.8 \mathrm{~km} / \mathrm{h}$ while the lowest value of tare ratio 
under the same conditions was $4.37 \%$. Under turbine cleaning system the highest value of tare ratio $5.71 \%$ and the lowest value of tare ratio $4.18 \%$ was observed under the same conditions of axial cleaning ratio. Similar results and trends were observed under TW2 system. The highest value of tare ratio $5.83 \%$ and the lowest value of 4.19 was achieved under forward speed of 5.8 and $3.5 \mathrm{~km} / \mathrm{h}$ respectively for the axial cleaning system. While the highest value of tare ratio for turbine cleaning system was 5.44 and lowest value was $4.11 \%$ were obtained under forward speed of 5.8 and $3.5 \mathrm{~km} / \mathrm{h}$ respectively. Generally, one can see that, there are a direct proportional between the tare ratio and tractor forward speed. Also, the minimum tare ratio achieved at turbine cleaning system and hydraulically driven of opal wheel.

The cleaning ratio $(\%)$ for the two split harvester at the tested forward speed $(\mathrm{km} / \mathrm{h})$, type of cleaning system and type of opal wheel driver for sugar beet (Cesira).

The chief reason for cleaning sugar beet is to remove the undesired materials such as clods and stones. Cleaning ratio (\%) for the two split harvester at the tested forward speed $(\mathrm{m} / \mathrm{s})$, type of cleaning system and type of opal wheel driver for sugar beet (Cesira) is presented on Figures. 5. The results showed that increasing forward speed resulted in decreasing cleaning ratio, $\%$. The overall data showed that, with the two cleaning system (axial and turbine) with TW1 system under forward speed of $3.5,4.3,5$ and $5.8 \mathrm{~km} / \mathrm{h}$, average of cleaning ratio was 95.723 , 95.292, 94.85 and $93.99 \%$, respectively. From the figures, it was clear that the cleaning ratio was higher with turbine cleaning than axial cleaning. The highest value of cleaning ratio $95.817 \%$ with turbine cleaning system was obtained under forward speed of $3.5 \mathrm{~km} / \mathrm{h}$ while the lowest value of cleaning ratio under the same conditions was $94.287 \%$. Under axial cleaning system the highest value of cleaning ratio $95.63 \%$ and the lowest value of cleaning ratio $93.693 \%$ was observed under the same conditions of turbine cleaning system. Similar results and trends were observed under TW2 system. Obviously, it was clear that with TW2 system, the cleaning ratio was higher than using TW1 system. Also from the figure cleaning ratio was lower in axial cleaning than turbine cleaning system. From the obtained data, the highest value of cleaning ratio was $95.89 \%$ and $95.81 \%$ for TW2 system and TW1 system, respectively under the same conditions of forward speed $3.5 \mathrm{~km} / \mathrm{h}$ and turbine cleaning system. All these results may be according to the increase in belts movement speed which resulted in transmit beets with cleaning that 
led to beet stuffed on the belt and consequently decreased the cleaning ratio. Data analyzed showed that there was a significant effect without using hydraulic system and with using hydraulic system $(\mathrm{p}<0.01)$ under the same conditions of forward speed and cleaning systems.

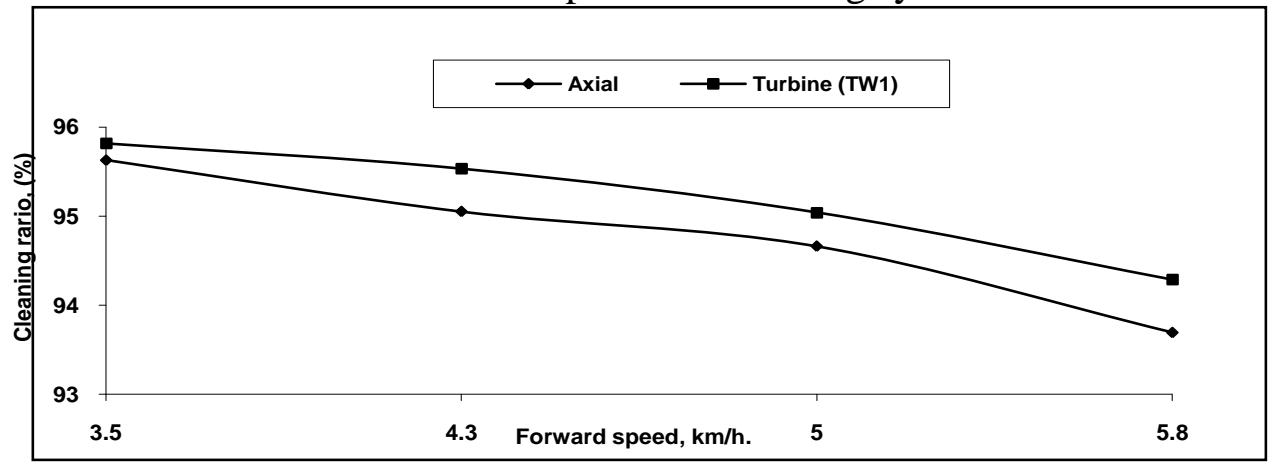

Figure. 5 : The cleaning ratio (\%) for the two split harvester at the tested forward speed $(\mathrm{km} / \mathrm{h})$, type of cleaning system and type without opal wheel driver for sugar beet (Cesira).

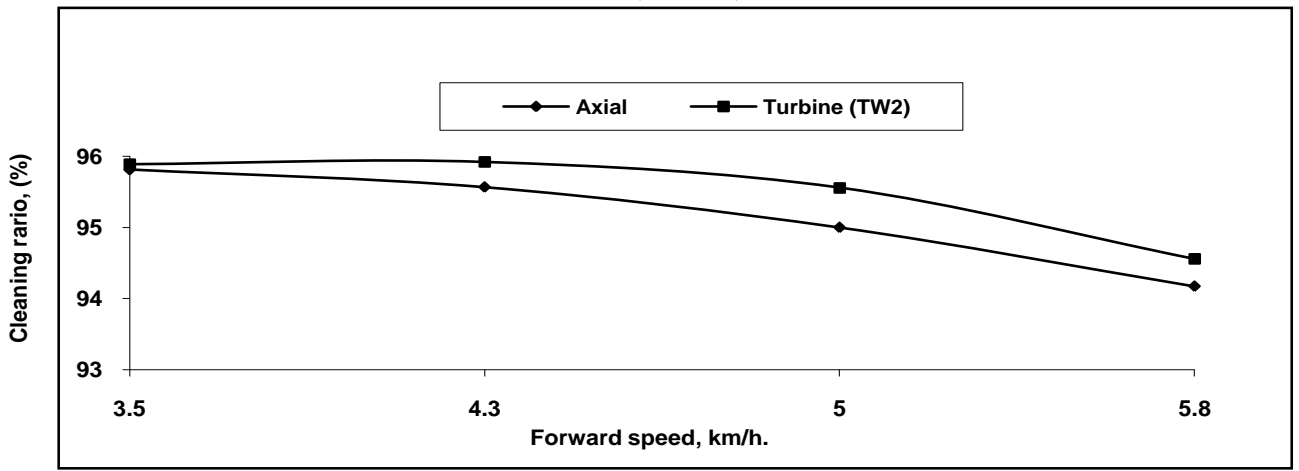

Figure. 5 : The cleaning ratio (\%) for the two split harvester at the tested forward speed $(\mathrm{km} / \mathrm{h})$, type of cleaning system and type with opal wheel driver for sugar beet (Cesira).

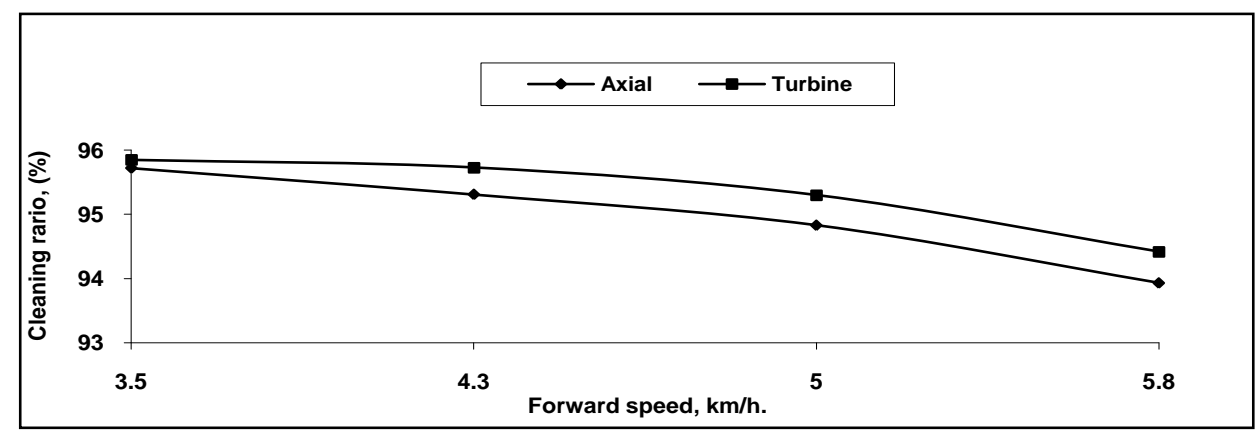

Figure.5: Average of the cleaning ratio (\%) for the two split harvester at the tested forward speed $(\mathrm{km} / \mathrm{h})$, type of cleaning system and types of opal wheel driver for sugar beet (Cesira). 


\section{The fuel consumption $(1 / h)$ for the two split harvester at the tested} forward speed $(\mathrm{km} / \mathrm{h})$, type of cleaning system and type of opal wheel driver for sugar beet (Cesira).

Figures 6 revealed that both type of cleaning system and type of opal wheel driver for sugar beet harvester affected deeply on the fuel consumption at constant forward speed. The results showed that increasing forward speed resulted in increasing fuel consumption $(1 / \mathrm{h})$. It was found that increasing forward speed from 3.5 to $4.3 \mathrm{~km} / \mathrm{h}$ resulted in increasing fuel consumption $(1 / \mathrm{h})$ from 17.19 to 18.17 with TW1 system under axial cleaning system. Similar trend was shown with forward speed of 5 and $5.8 \mathrm{~km} / \mathrm{h}$. The overall data showed that, with the two cleaning system (axial and turbine) with TW1 system under forward speed of 3.5, $4.3,5$ and $5.8 \mathrm{~km} / \mathrm{h}$, average of fuel consumption $(1 / \mathrm{h})$ was $17.51,17.78$, 18.13 and 18.57 , respectively. From the figures, it was clear that the fuel consumption $(1 / \mathrm{h})$ was higher with axial cleaning system than turbine cleaning system. The highest value of fuel consumption (1/h) 18.97 with axial cleaning was obtained at forward speed of $5.8 \mathrm{~km} / \mathrm{h}$ while the lowest value of fuel consumption $(1 / \mathrm{h})$ under the same conditions was 17.19. Under turbine cleaning system the highest value of fuel consumption (1/h) 18.17 and the lowest value of fuel consumption $(1 / \mathrm{h})$ 17.10 was observed under the same conditions of axial cleaning ratio. Similar results and trends were observed under $\mathrm{TW}_{2}$ system. Obviously, it was clear that with $\mathrm{TW}_{2}$ system, the fuel consumption $(1 / \mathrm{h})$ was less than using $\mathrm{TW}_{1}$ system. Data analyzed showed that there was a significant effect for without using hydraulic system and with using hydraulic system $(p<0.01)$ under the same conditions of forward speed and cleaning systems. Also, there was a significant effect by decreasing forward speed from 5.8 to $3.5 \mathrm{~km} / \mathrm{h}$.

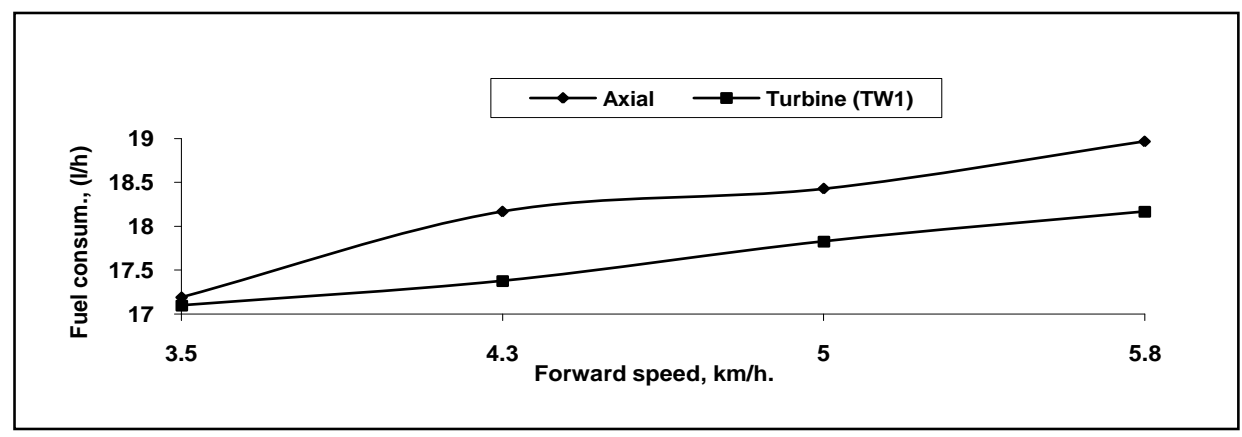

Figure. $6_{\mathrm{a}}$ : Fuel consumption $(1 / \mathrm{h})$ for the two split harvester at the tested forward speed $(\mathrm{km} / \mathrm{h})$, type of cleaning system and type without opal wheel driver for sugar beet (Cesira). 


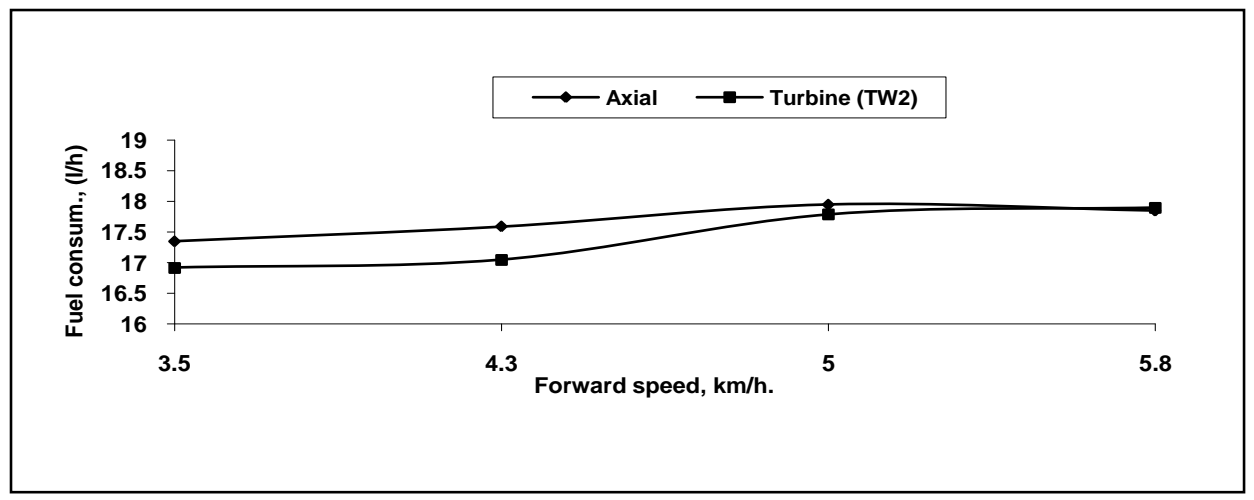

Figure. $6_{b}$ : Fuel consumption $(1 / h)$ for the two split harvester at the tested forward speed $(\mathrm{km} / \mathrm{h})$, type of cleaning system and type with opal wheel driver for sugar beet (Cesira).

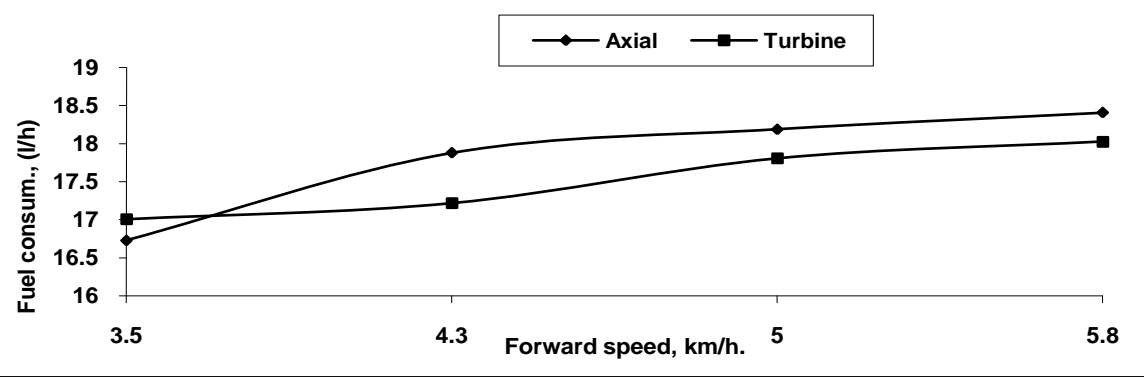

Figure $6_{c}$ : Average of fuel consumption $(1 / h)$ for the two split harvester at the tested forward speed $(\mathrm{km} / \mathrm{h})$, type of cleaning system and two types of opal wheel driver for sugar beet (Cesira).

\section{REFERENCES}

Abd - Rabou. A.F., 2004. Manufacturing a small machine to suit harvesting sugar beet under Egyptian conditions. Ph. D., Thesis. Agric. Mech. Dept., Fac. Agric., Kafr El-Sheikh. Tanta Univ. P: 33-131.

Aly, A.H., 1998. Design and development of a sugar beet topper. Ph.D., Thesis. Agric. Mech . Dept., Fac. Agric., Ain Shams Univ. P: 57146. 
Awad, M.A., 2006. Developing of a pulling out mechanism for harvesting sugar beet crop. Ph.D. Thesis. Agric. Eng. Dept., Fac. Agric., Mansoura Univ. P: 28-

Ivancan. S; Sito .S. And G . Fabiganic.2002. Bodenkultur .53 (3):161166.

Kepner, R.A.; R. Baine and E.L Barger (1982) Principles of farm machinery, $2^{\text {nd }}$ Ed. CBS Publisher, Distributors, India, : 464-468.

Khalil.N.A.,2007. Design and construction of sugar beet harvesting machine suitable for Egyptian condition. M.Sc., Thesis. Production Eng. And Mechanical Design. Dept., Fac, Engineering. Tanta Univ. P: 39-129.

Kromer, K.H.;M.Thelen And P . Degen. 1998. States Of Sugar Beet Harvesting In Europe: Comparison Of Harvesting Systems Zuck. Germany . 123(10) : 816-821.

Richey, C.B., P. Jacobson. and C. Hall., 1961. Agricultural engineers' Hand book. McGrow - Hill books Co, INC. New - York. USA. P: $270-274$.

Suliman, A.E.; G.E.M. Nasr and W.M.I. Adawy (1993). Energy requirements for land preparation of peas crop under Egyption conditions. Misr. J. Agric., 10(2): 190-206.

SharobeemY.F;I.M. Abd El-Tawwab and S. El-Khawaga.,2003. Design And Construction Of A Three Row Lifting Machine For Sugar Beet Misr, Jou, Agr , Eng, 20. (4), 980-992.

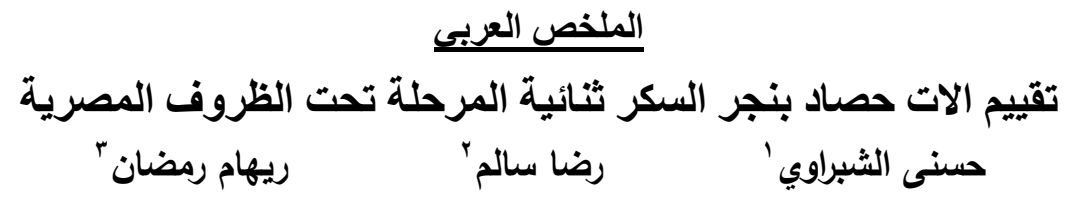

أجريت هذه التجربة على مساحة ...7 فدان فى شركة النوران بالصالحية بمحافظة الثرقية

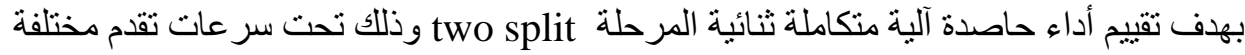
للحاصدة لحصاد محصول بنجر السكر. وقد نم تحديد أربعة عوامل للاراسة لاختبار تأثيرها

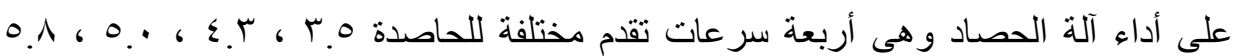
'ـ أستاذ الهندسة الزراعية ـ كلية الزراعية - جامعة المنصورة

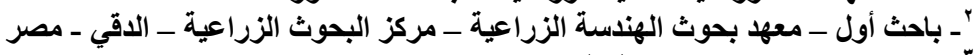

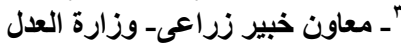




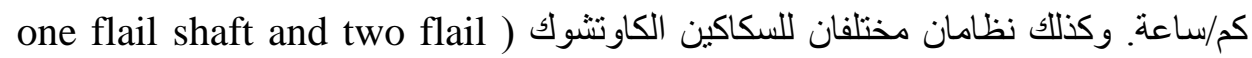
( ) بلإضافة لعمود الساكين الصلب وكذلك وجود نظامين للأقراص الخلفية الملحقة (shaft ground driven وكذلك نظامين لاقر اص التقائ لنقيع (with Scraper and without scraper

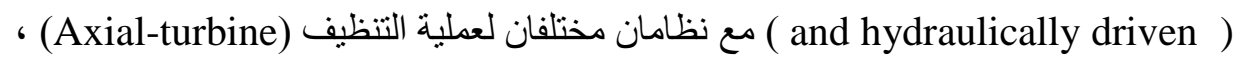
وقد تم قياس كل من النسبة المئوية للجذور الغير مطوشة والنسبة المئوية الثوائب و نسبة التنظيف و استهلاك الوقود (لتر /ساعة)

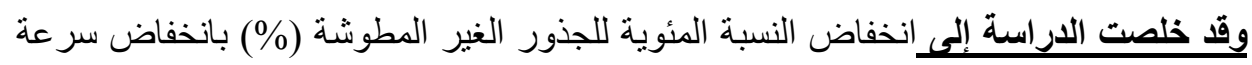

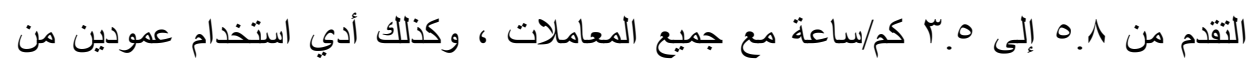

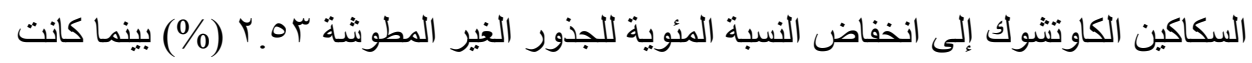

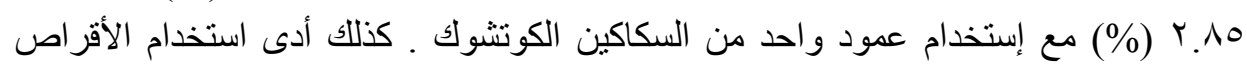

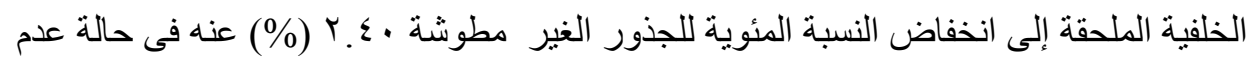

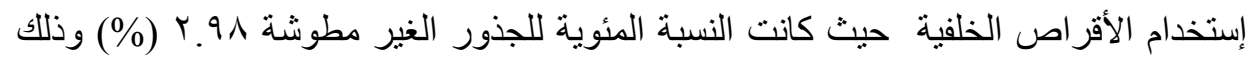
عند نفس ظروف التشغيل. وقد أدى زيادة سر عة التقدم إلى زيادة نسبة الثُ النّائب مع استخدام كلا

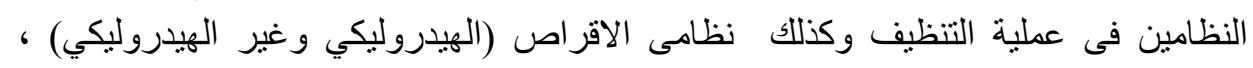

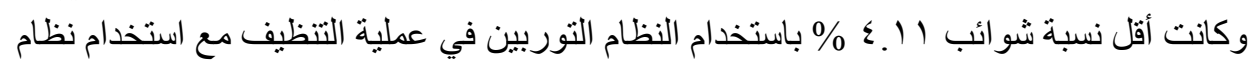

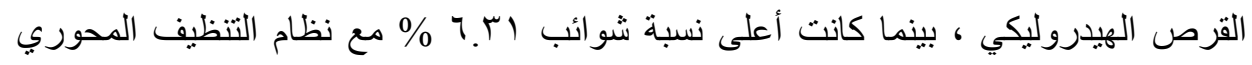

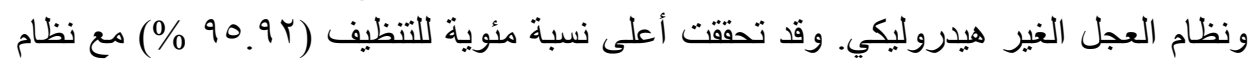

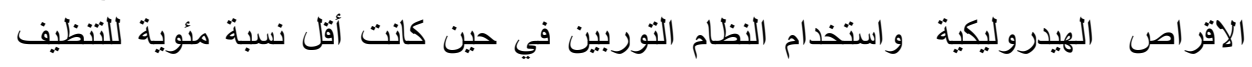
9 ؟. Y NV

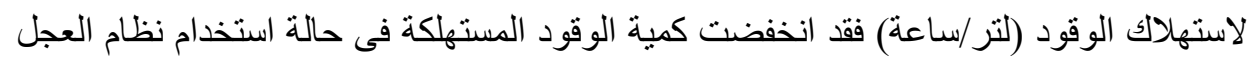

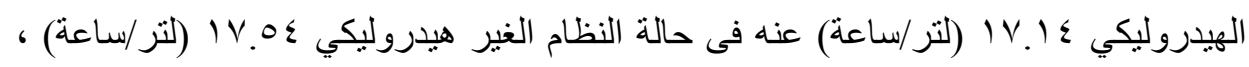

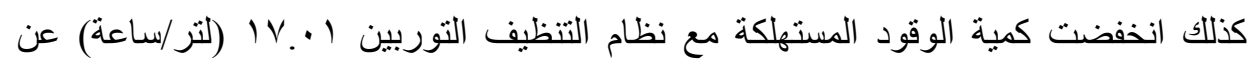

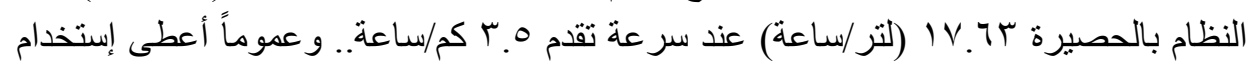

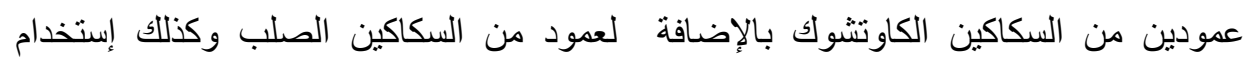

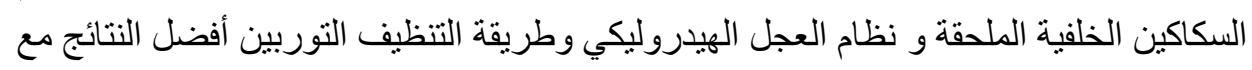
جميع المعاملات. 